\title{
PERFORMANCE AND HETEROTIC ESTIMATION OF GROWTH IN INTRASPECIFIC CROSSING OF GIANT GOURAMY
}

\author{
Didik Ariyanto\# and Nunuk Listiyowati \\ Research Institute for Freshwater Fish Breeding and Aquaculture
}

(Received 4 March 2011 ; Accepted 20 June 2011 )

\begin{abstract}
Intraspecific crossing of giant gouramy was done to get better hybrid population. This study was conducted to evaluate the hybrid vigour or heterotic value of the hybrids line, especially for growth rate character. Besides that, we want to know the effect of hybridization on performance of phenotypic variability. Two days post hatching age larvae of four populations i.e. Bastar and Blue-saphire strain, F-1 hybrid and F-1 hybrid reciprocal, were used in this experiment. All fish were reared in aquaria for 30 days period in indoor hatchery. The fish were fed with live food such as Moina and Daphnia for the first ten days, followed by Tubifex for the second ten days and finally, commercial feed were given until the end of the study. The collected data were total length, standard length, and body weight of each population. The results showed that the phenotypic variability of the hybrid population was higher than that of inbred population. Hybrid population from female of Bastar and male of Blue-saphire has better growth than both of its parents. Heterotic values of total length, standard length, and body weight of the hybrid population was $9.5 \%, 2.9 \%$, and $15.6 \%$ respectively. Maternal effect was detected in hybrid population.
\end{abstract}

KEYWORDS: Giant gouramy, intraspecific crossing, heterotic value, growth

\section{INTRODUCTION}

Giant gouramy (Osphronemus gouramy) is one of indigeneous fish species from Indonesia. This species was one of ten important commodities in aquaculture. Gouramy culture was relatively easy. As a herbivorous fish, gouramy can be cultured with no additional artificial food. Besides that, gouramy can live normally in low quality water because it has a labyrinth apparatus, an additional breath organ for the species. According to Sudarto (1989), there were several strains of giant gouramy, such as Soang, Blue-saphire, Paris, Porselen, and Bastar. In the market, gouramy has higher price than other fish cultured, especially in freshwater culture system.

On the other hand, the low growth of this commodity is the main constrain to develop its culture. Breeding program to improve the growth character is the rational solution for that problem. One of the first steps in the breeding program for giant gouramy is identifying and characterizing the important economical traits, especially for growth and survival rate. Early studies to identify the base characters of gouramy have been done by several researchers. Suwardi (1993) trough electrophoresis enzyme method reported that

\# Corresponding author. Research Institute for Freshwater Fish Breeding and Aquaculture Jl. Raya 2 Sukamandi, Subang 41256, West Java, Indonesia. Tel.: +62 260520500

E-mail address: didik_ski@yahoo.com 
several strains of giant gouramy, such as Bluesaphire, Soang, Bule, Batu, and Bastar have a low genetic variability. According to this report, the genetic distance between Batu and Blue-saphire strain was so close as they have a similar genetic structure. This report suspected that both of them were developed from the same strain. Moreover, this report explained that both of Batu and Blue-saphire strain have a little genetic distance with Soang and Bule strain but far with Bastar strain.

Another study which was conducted by Setijaningsih et al. (2004) showed that the Bastar strain has a faster growth rate than others strain. This study also reported that Bluesaphire strain has a higher fecundity than others. So, this report suggested that both of Bastar and Blue-saphire strains can be selected as the broodstock in the breeding program. Based on these study report, the best breeding program which can be applied for cultured giant gouramy is cross-breeding especially for Bluesaphire or Batu strain which can be potentially crossed with Bastar strain.

This study was conducted to know the effect of intraspecific crossing of giant gouramy, especially the phenotypic variability as the result of genotypic variability and to evaluate the heterotic value of growth character of intraspecific hybridization of giant gouramy, especially for Blue-saphire strain crossed with Bastar strain.

\section{MATERIALS AND METHODS}

\section{Fish Material and Spawning}

Four populations of giant gouramy were selected for this study, i.e.Bastar strain (P-1), Blue-saphire strain (P-2), F-1 and F-1 reciprocal from full diallel crossing of $P-1$ and $P-2$. Bastar strain was obtained from Bogor and the Bluesaphire strain was from Tasikmalaya. Both of two populations were transferred to Sukamandi station for adaptation and spawning. The selected mature male broodstocks were separated from the female for two weeks before pooled in the spawning ponds. Natural spawning was carried out in earthen ponds, sized $7 \mathrm{~m} \times 7 \mathrm{~m}$, with fish ratios of male to female was $1: 3$. The total number of fish for spawning was 8 fish for each spawning combination. Scheme of full diallel crosses of giant gouramy in this experiment was shown in Table 1.
Table 1. Scheme of full diallel crosses between Bastar strain (AA) and Bluesaphire strain (BB)

\begin{tabular}{lll}
\hline $0^{*}$ & AA & BB \\
\hline$A A$ & AA-AA & AA-BB \\
$B B$ & BB-AA & BB-BB \\
\hline
\end{tabular}

Explanation: $\mathrm{AA}=$ Bastar, $\mathrm{BB}=$ Blue-saphire

During the spawning time, the broodstock were fed with commercial feed containing $30 \%-32 \%$ of crude protein. The feed was given with feeding rate about $3 \%, 3$ times a day. Besides the commercial feed, natural feeds like sente leaf (Alocasia macrorhiza), were given ad libitumly.

\section{Egg Collection and Fry Rearing}

Egg checking in the nest was regularly conducted every day, two weeks after the broodstocks were pooled. The nest with eggs in it was lifted up and then put in a basket. The eggs were then manually separated from the nest and other waste. The eggs as soon as possible were placed in artificial hatching trays and will hatch in 3-5 days later. Two days after hatching, the larvae were reared in aquaria with the size of $60 \mathrm{~cm} \times 40 \mathrm{~cm} \times 50 \mathrm{~cm}$ with artificial aeration from installed hi-blower. The fish density was 1 fish for 5 L of media. Life food which was Artemia salina was given for the first ten days, followed by Moina dan Daphnia for second ten days. Commercial feed containing of $40 \%$ crude protein was given until the $30^{\text {th }}$ day. All feeds were given at satiation. Siphoning and 30\%-50\% water exchange were done on each aquarium every 2 days.

\section{Parameters and Data Analysis}

The parameters observed for analysis of fish performance were total length, standard length, and body weight every 10 days. All data were tabulated and analyzed with SPSS program version 12 .

Heterotic value of the hybrid population was estimated according to Tave (1993):

$$
\mathrm{H}=\frac{\begin{array}{l}
\text { Average of resiprocal } \mathrm{F} 1 \text { hybrid }- \\
\text { Average of its parents }
\end{array}}{\text { Average of its parents }} \times 100 \%
$$




$$
\begin{gathered}
\text { Resiprocal }=\frac{A B+B A}{2} \\
\text { Parents }=\frac{A A+B B}{2}
\end{gathered}
$$

Explanation:

$$
\begin{aligned}
& H=\text { Heterotic value estimated } \\
& A B=\text { Crossing of } A A(\text { sire) with } B B(\text { dam) } \\
& B A=\text { Crossing of } B B(\text { sire) with } A A(\text { dam) } \\
& A A=\text { Crossing between its parents of } A A \\
& B B=\text { Crossing between its parents of } B B
\end{aligned}
$$

\section{RESULTS AND DISCUSSION}

\section{Distribution and Variability of Population}

One of important steps in a breeding program is characterization of the object population including the distribution and variability of the population, combining ability among populations and heterotic estimation especially in hybridization program, heritability, and breeding value in selective breeding program etc. Variability of population can be analyzed trough several methods, i.e. phenotypic, enzymatic, and genetic approach.

Total length, standard length, and body weight of each population observed at the $10^{\text {th }}$, $20^{\text {th }}$, and $30^{\text {th }}$ were shown in Table 2 . Based on those observed phenotypic, individual weight distribution of population of giant gouramy in this study followed the normal distribution curve (Figure 1). But, the skewness which tends to the left indicated that the populations of giant gourame were potentially low for selec- tion due to small number of individual fish sized more than the average weight.

Except from the individual distribution data, the variability of population can be evaluated from the coefficient of variance value of the population. Noor (2000) stated that coefficient of variance value for one character indicates the level of variability of that character. The level of phenotypic variability expresses the genetic variability. According to Table 2, coefficient of variance value of total length, standard length, and body weight for inbreed line population of Bastar (AA $\times$ AA) was low (5.21\%$16.57 \%)$. This condition indicated that the genetic variability of this population was low. Further more, Noor (2000) also explained that genetic variability correlated with homozygous and heterozygous gene proportions. Lower heterozygous gene proportion means that the genetic variation is also low. The low genetic variability in cultured stock is a common phenomenon for several species, i.e. Imron et al. (1999) in tiger shrimp (Penaeus monodon), Myers et al. (2001) in coho salmon (Oncorhynchus kisutch), Permana et al. (2001) in humpback grouper (Cromileptes altivelis), Agnese (1997) in Romana-Eguia (2004) in nile tilapia (Oreochromis niloticus) Frost et al. (2006) in barramundi (Lates calcarifer), MachadiSchiaffino et al. (2006) in Atlantic salmon (Salmo salar), and Perez-Enriquez et al. (2009) in white shrimp (Penaeus vannamei). According to these reports, several factors can cause the reduction of genetic variability in cultured stock such as improper broodstock management, selection activity, inbreeding depression and random genetic drift or bottleneck effect that is caused by a small founding population in hatch-

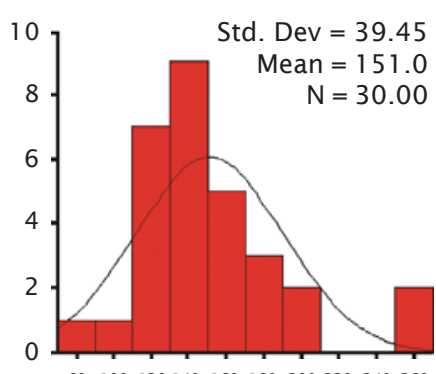

80100120140160180200220240260

BBT

Individual weight distribution of $A A \times A A$

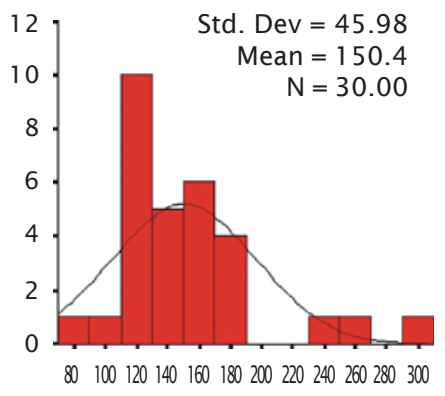

BBT

Individual weight distribution of $A A \times B B$

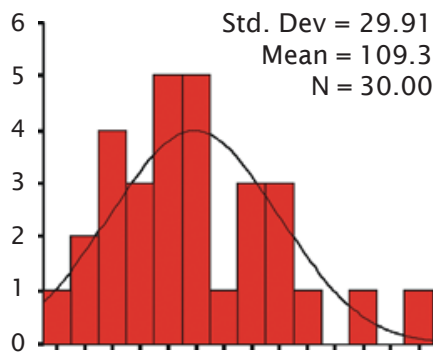

60708090100110120130140150160170180190

BBT

Individual weight distribution of $B B \times A A$

Figure 1. Distribution of individual weight of three populations of giant gouramy 


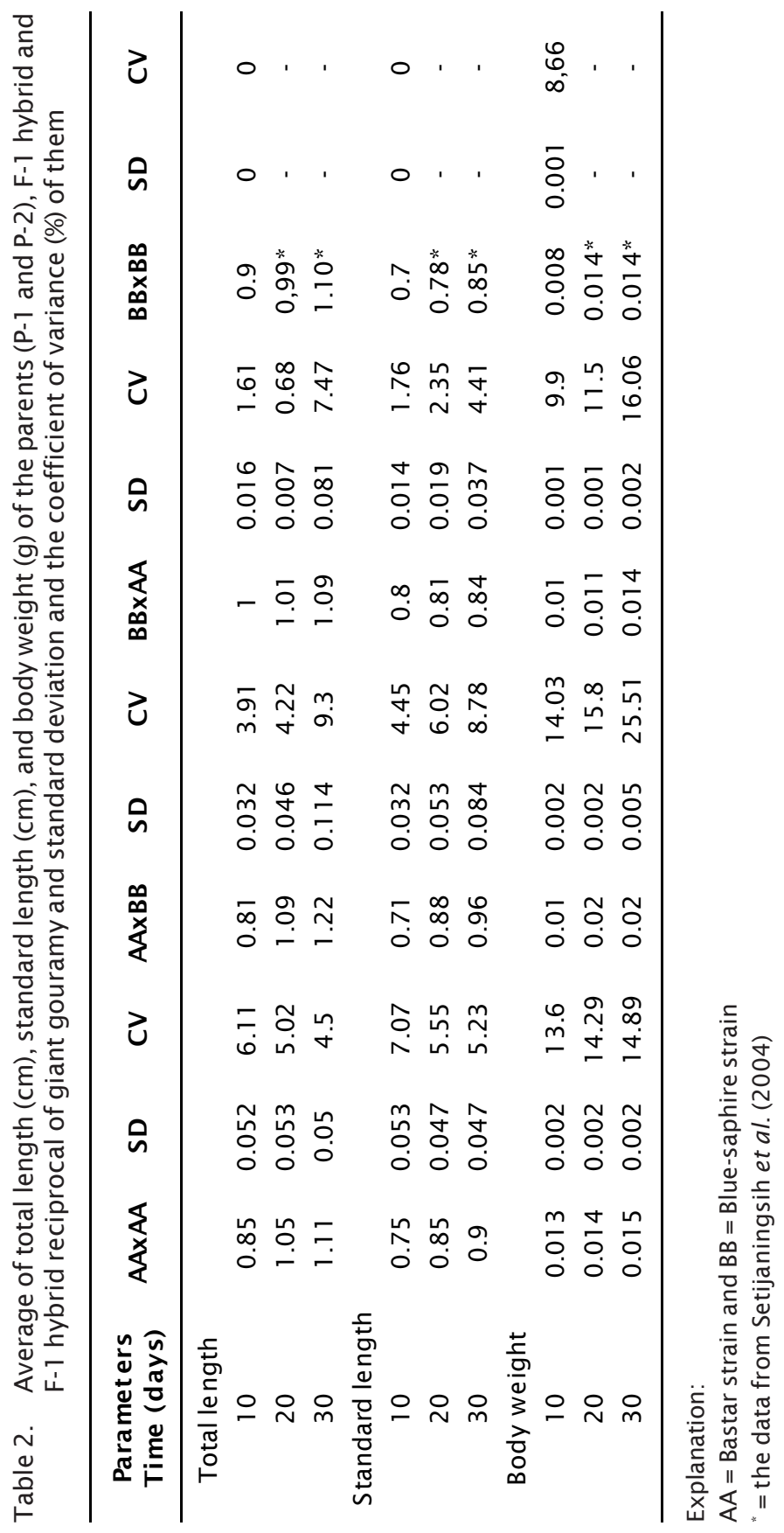


ery. Beside that, high frequency of broodstock distribution between two or more of hatchery or seed production centers might affect to closeness of genetic distance due to genetic introgression among them.

In terms of genetic improvement of a population, an alternative way to increase the genetic variability is trough hybridization (Tave, 1996). Intraspecific crossing of female Bastar with male of Blusafir $(A A \times B B)$ resulted higher coefficient of variance value for the same character, ranged from $5.81 \%$ to $18.45 \%$. It means that this cross segregation would increase the proportion of heterozygous gene of its offspring.

\section{Heterotic Value of Growth}

Another purpose of hybridization is to get hybrid population with faster growth performance. Based on Table 2, intra-specific crossing of giant gouramy, especially for female of Bastar strain with male of Blue-saphire strain $(A A \times B B)$, would increase the growth rate. This crossing produced the progeny with higher individual weight than its parent, especially than the Bastar strain. Noor (2000) stated that if fish that have no family relationship are crossed, it will show a better performance than one or both of its parents. The different level of performance of the progeny compared to its parents was called hybrid vigour, which its quantification can be estimated. The estimation value of hybrid vigour was called heterotic. Based on the Table 2, heterotic value of growth rate, indicated with total length, standard length, and body weight characters, for intraspecific crossing of giant gouramy in this study were shown in Table 3.
Heterotic value explained the performance between the offspring and its parents. Heterotic value also showed that the progeny which was obtained from the hybridization has higher or lower performance than its parents, for specific trait (Warwick et al., 1990). Heterotic value of total length, standard length, and body weight in intraspecific crossing of Bastar and Blue-saphire strain in this study were $9.5 \%, 2.9 \%$, and $15.6 \%$, respectively. According to this results, intraspecific crossing of Bastar strain with Blue-saphire strain resulted the positive heterotic, means that the progeny has a better growth rate that its parents. According to Noor (2000), the low to medium heterotic value observed in this experiment indicated the closeness of genetic distance between these strains. Dunham (1995) said that there are general problem occurred in the intraspecific hybrid, compared with interspecific hybrid. This result according to Subagyo et al. (1999) in Ariyanto \& Subagyo (2004) that the heterotic value of weight in intraspecific of common carp (Cyprinus carpio) was low to medium, ranged 10,55\%-13,48\%. But heterotic value of the same character for interspecific of catfishes (Pangasius djambal $x$ P. hypophthalmus) was relatively high, about 48,28\% (Ariyanto \& Utami, 2005).

Besides genetic relationship, heterotic value can also be affected by gene action mechanisms. Generally, heterotic value showed non additive gene action, which contained full dominance action, over-dominance action and epistatic. The low effect of both of over-dominance gene action and epistatic in the progeny which was obtained from this hybridization showed that this activity is a full

Table 3. Estimation of heterotic value (\%) for total length, standard length and body weight characters in full diallel crossing of giant gouramy

\begin{tabular}{lccc}
\hline \multicolumn{1}{c}{$\begin{array}{c}\text { Diallel crossing of Bastar (AA) } \\
\text { and Blusafir (BB) }\end{array}$} & $\begin{array}{c}\text { Total } \\
\text { length }\end{array}$ & $\begin{array}{c}\text { Standard } \\
\text { length }\end{array}$ & $\begin{array}{c}\text { Body } \\
\text { weight }\end{array}$ \\
\hline Parents & & & \\
$\quad$ - Female Bastar (AA) x Male Bastar (AA) & 1.105 & 0.900 & 0.0148 \\
$\quad$ - Female Blusafir (BB) x Male Blusafir (BB) & 1.100 & 0.850 & 0.0140 \\
Reciprocal crossing & & & \\
$\quad$ - Female Bastar (AA) x Male Blusafir (BB) & 1.220 & 0.960 & 0.0196 \\
- Female Blusafir (BB) x Male Bastar (AA) & 1.085 & 0.840 & 0.0137 \\
Heterotic value estimation (\%) & 9.50 & 2.90 & 15.60 \\
\hline
\end{tabular}




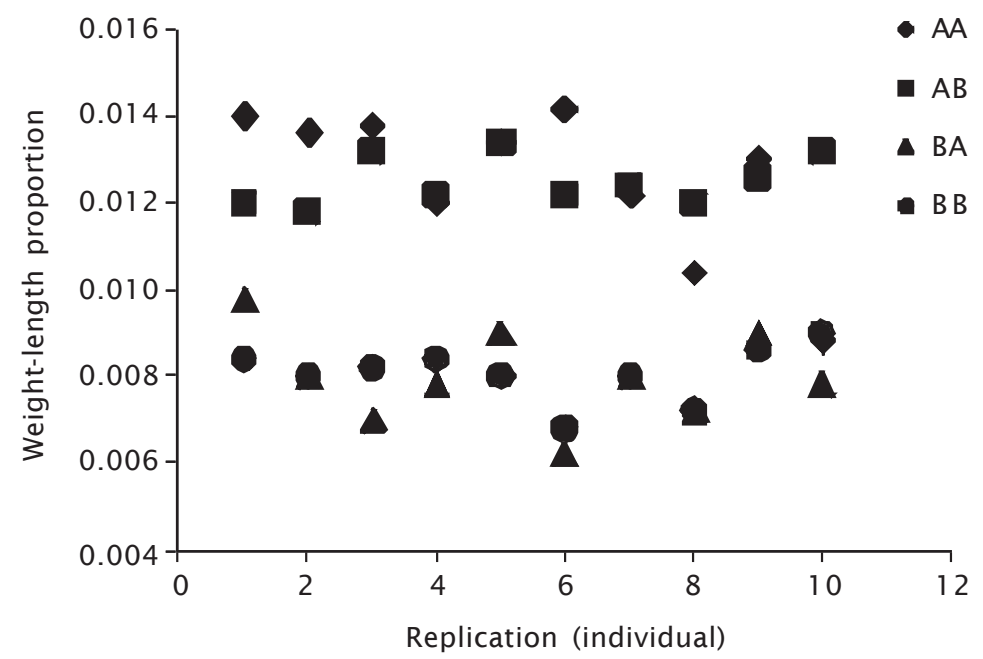

Figure 2. Shape performance of individual seed (weight-length proportion) which showed the maternal effect in diallel crossing of giant gouramy

dominance gene action exploitation. (Tave, 1993). In spite of the heterotic value for growth rate in this study was low to medium, but it can be seen that dominance effect was detected for the reciprocal crossing. This phenomenon was suspectedly to be caused by maternal effects, which can be seen in Figure 2. Based on the Figure 2, it is clearly showed that the shape performance of both of hybrid populations $A A \times B B$ and $B B \times A A$ followed the female shape performance of its parents.

Heterotic value of growth character in this experiment was low to medium, so it was predicted that the hybridization program was not too effective to improve the performance of giant gouramy. According to these results, it is suggested to exploit the additive variance of population trough individual or family selection, especially from wild population. Beside that, transgenesis program to form the super growth transgenic fish might be developed in the future.

\section{CONCLUSION}

1. Intraspecific crossing in giant gouramy increased the phenotypic variability, especially for total length, standard length, and body weight.

2. Heterotic value for total length, standard length, and body weight characters of the crossbreed of Bastar strain with Blue- saphire strain were $9.5 \%, 2.9 \%$, and $15.6 \%$, respectively.

3. There is a maternal effect phenomenon in F- 1 and F-1 reciprocal crossbreed of Bastar strain with Blue-saphire strain.

\section{REFERENCE}

Ariyanto, D. \& Subagyo. 2004. Keragaman genetik dan evaluasi heterosis pada persilangan antar galur dalam spesies ikan mas (Cyprinus carpio). Zuriat, 15(2): 118 124.

Ariyanto, D. \& Utami, R. 2005. Evaluasi pertumbuhan, keragaman genetik dan estimasi heterosis pada persilangan antar spesies ikan patin (Pangasius sp.). J. Perikanan, VII(1): 81-86.

Dunham, R.E. 1995. The contribution of genetically improved aquatic organisms to global food security. Intl. Conf. On "Sustainable contribution of fisheries to food security". KC/Fl/Tech. 6. Rome, 111 pp.

Frost, L.A., Evans, B.S., \& Jerry, D.R. 2006. Loss of genetic diversity due to hatchery culture practices in barramundi (Lates calcarifer). Aquaculture, 261: 1,056-1,064.

Imron, Sugama, K., Sumantadinata, K., \& Soewardi, K. 1999. Genetic variation in cultured stock of tiger shrimp (Penaeus monodon) in Indonesia. Indonesian Fish. Res. J., V(1): 10-18. 
Lenormand, S., Slembrouck, J., Pouyaud, L., Subagja, J., \& Legendre, M. 1998. Evaluation of Hybridisation in Five Clarias Species (Siluriformes, Claridae) of African ( $C$. gariepinus) and Asian Origin (C. batrachus, C. meladerma, C. nieuhofii, and $C$. teijsmanni). In: Legendre, M. \& Parisele, A. The Biological Diversity and Aquculture of Clariid and Pangasiid Catfishes in ShoutEast Asia. Proceeding of The Mid-Term Workshop of The "Catfish Asia Project". Cantho, Vietnam, 11-15 Mei 1998, p. 195-209.

Machado-Schiaffino, G., Dopico, E., \& GarciaVazquez, E. 2006. Genetic variation losses in Atlantic salmon stocks created for supportive breeding. Aquaculture, 264: 5965.

Myers, J.M., Heggelund, P.O., Hudson, G., \& Iwamoto, R.N. 2001. Genetics and broodstock management of coho salmon. Aquaculture, 197: 43-62.

Noor, R R. 2000. Genetika ternak. Penebar Swadaya. Jakarta, $197 \mathrm{pp}$.

Perez-Enriquez, R., Hernández-Martínez, F., \& Cruz, P. 2009. Genetic diversity status of White shrimp Penaeus (Litopenaeus vannamei) broodstock in Mexico. Aquaculture, 297: 44-50.

Permana, I.G.N., Moria, S.B., Haryanti, \& Sugama, K. 2001. Pengaruh domestikasi terhadap variasi genetik ikan kerapu bebek (Cromileptes altivelis) yang dideteksi dengan allozyme electrophoresis. J. Pen. Perik. Indonesia, 7(1): 25-30.

Romana-Eguia, M.R.R., Ikeda, M., Basiao, Z.U., \& Taniguchi, N. 2004. Genetic diversity in farmed Asian Nile and red hybrid tilapia stocks evaluated from microsatellite and mitochondrial DNA analysis. Aquaculture, 236: 131-150.

Setijaningsih, L., Hadie, L.E., Gunadi, B., \& Ariyanto, D. 2004. Pembentukan populasi dasar dari beberapa ras ikan gurame melalui program selective breeding. Kumpulan Makalah Seminar Hasil Riset LRPTBPAT, 8 pp.

Soewardi, K. 1995. Karakterisasi populasi ikan gurame (Osphronemus gouramy Lacepede), dengan metode biokimia. J. IImu Perairan dan Perikanan Indonesia, III(2): 3339.

Sudarto. 1989. Porselin, Blusafir dan paris yang bertelur. Warta Penelitian dan Pengembangan Pertanian, 11 (2): 1-2.

Tave, D. 1993. Genetik for fish hatchery managers. The AVI Publ. Comp. Inc., NY, USA. $2^{\text {nd }}$ ed., 418 pp.

Tave, D. 1996. Selective breeding programmes for medium-sized fish farms. FAO Fish. Tech. Paper 352, 122 pp.

Warwick, J.W., Astuti, W., \& Hardjosubroto. 1995. Pemuliabiakan ternak. Gadjah Mada University Pers, 490 pp. 